\title{
RENDEMENKAYU KARET RAKYAT DAN SENGON PADA PRODUKSI VENEER CORE PLYWOOD
}

\author{
Raja Asmunriyan 1), Rina Novia Yanti 2), Ambar Tri Ratnaningsih 2) \\ 1) Mahasiswa Fakultas Kehutanan Universitas Lancang Kuning \\ 2) Staf Pengajar Fakultas Kehutanan Universitas Lancang Kuning \\ JIn. Yos Sudarso Km. 8 Rumbai Pekanbaru Riau \\ Email :rajaasmunriyan@gmail.com,rina_fahutanunilak@yahoo.co.id,ambar_trn@yahoo.com
}

\begin{abstract}
ABSTRAK
Suplai bahan baku industri plywood pada saat ini terbatas karena kondisi hutan alam yang tidak memungkinkan lagi untuk memenuhinya. Salah satu upaya yang ditempuh untuk memenuhi kebutuhan bahan baku adalah mencari sumber bahan baku yang berasal dari hutan tanaman, hutan rakyat ataupun perkebunan diantaranya tanaman Karet rakyat dan Sengon yang dimanfaatkan sebagai bahan baku veneer core. Perbedaan jenis bahan baku veneer core akan menghasilkan perbedaan rendemen. Penelitian ini bertujuan untuk membandingkan rendemen kayu karet rakyat dan sengon dalam pembuatan veneer core di industri plywood PT. Ewan Superwood yang terletak di Propinsi Riau dan menentukan faktor-faktor yang mempengaruhi rendemen. Populasi penelitian ini adalah kayu karet rakyat dan sengon dengan mengambil sampel sebanyak 60 batang yang terdiri dari 30 batang kayu karet rakyat dan 30 batang kayu sengon yang diambil secara acak. Rata-rata nilai rendemen veneer core yang berasal dari Kayu Karet Rakyat adalah $66,63 \%$. Rata-rata nilai rendemen veneer core yang berasal dari Kayu Sengon adalah $74,65 \%$. Faktor yang mempengaruhi rendemen veneer core pada kayu karet adalah Kondisi bahan baku ,diameter, keselindrisan dan cacat kayu yang disebabkan oleh bekas sadapan. Sedangkan pada kayu sengon dipengaruhi oleh adanya empelur yang rapuh.
\end{abstract}

Kata kunci : Rendemen, plywood, vener core, kayu karet, kayu sengon 